Cornell University Law School Scholarship@Cornell Law: A Digital Repository

$1-2017$

\title{
Inter-American Court Recognizes Elevated Status of Trade Unions, Rejects Standing of Corporations
}

Angela B. Cornell

Cornell Law School, abc49@cornell.edu

Follow this and additional works at: http://scholarship.law.cornell.edu/facpub

Part of the Human Rights Law Commons

\section{Recommended Citation}

Angela B. Cornell, "Inter-American Court Recognizes Elevated Status of Trade Unions, Rejects Standing of Corporations," 3 International Labor Rights Case Law (2017)

This Article is brought to you for free and open access by the Faculty Scholarship at Scholarship@Cornell Law: A Digital Repository. It has been accepted for inclusion in Cornell Law Faculty Publications by an authorized administrator of Scholarship@Cornell Law: A Digital Repository. For more information, please contact jmp8@cornell.edu. 


\title{
Commentary
}

\section{Inter-American Court Recognizes Elevated Status of Trade Unions, Rejects Standing of Corporations}

\author{
By Angela B. Cornell, Clinical Professor of Law and Director Cornell \\ University Labor Law Clinic, Cornell University Law School, United States
}

\section{Introduction}

The Inter-American Court was unanimous in concluding that legal entities do not have the standing to directly access the Inter-American system in a contentious process as presumptive victims. ${ }^{1}$ Corporations therefore will not be permitted to access the Court as victims of human rights transgressions, which the Court determined is limited to human beings, with two exceptions: trade unions and indigenous communities. Trade unions have standing as victims of human rights violations on their behalf and that of their members, but under certain limitations. This commentary focuses on the Court's decision with regard to trade unions, but begins with a description of the heart of the decision limiting the access of other legal entities. ${ }^{2}$

1 Inter-American Court of Human Rights, The Standing of Legal Entities in the Inter-American Human Rights System, Advisory Opinion OC-22/16, 26 February 2016.

2 The author was involved in the case on behalf of the International Commission for Labor Rights and working alongside the International Trade Union Federation (ITUC), participated in the oral argument before the Court in San Jose, Costa Rica, and with the preparation of the post-argument brief. As of the time of publication of this article, the decision was available only in Spanish. 


\section{Legal Entities Lack Standing in Inter-American Human Rights System}

Taking a comprehensive approach to its analysis, the Court began with a literal interpretation of the language and concluded that the plain language of Article 1(2) of the American Convention on Human Rights, which states that "for the purposes of this Convention, 'person' means every human being," clearly referred to human beings, to the exclusion of legal entities. ${ }^{3}$ The Court went on to consider the object and purpose of the treaty, the context, and the doctrine of dynamic interpretation of human rights instruments. Considering the matter from different analytical perspectives did not alter the conclusion. The object and purpose of the American Convention, the Court determined, is the "protection of the fundamental rights of human beings." ${ }^{4}$ In its analysis of context, the Court looked to other agreements and instruments in the Inter-American system, including the American Declaration on the Rights and Duties of Man and the Preamble to the American Convention, both of which confirm the commitment to the protection of the essential rights of the human being and use terms like "the human person." 5

The Court added another layer of analysis in looking outside the hemisphere and including a comparative perspective when it considered the standing and access of legal entities in the principal international human rights tribunals and jurisprudence of the European, African, and universal systems. Citing Vienna Convention Article 31 in regard to the use of other relevant international law on interpreting treaties, the Court compared the differing approaches to the standing issue for legal entities, starting with the European Convention for the Protection of Human Rights and Fundamental Freedoms, which is perhaps the most distinct. ${ }^{6}$

The European Convention on Human Rights differs somewhat from the American Convention, and these differences support the European position that legal entities can or should be able to access the human rights system. Unlike its American counterpart, the European Convention does not define the term person or the expression "every person"; nor does it specify whether

3 American Convention of Human Rights, OAs Official Records, oEA/Ser.A/16 (English), T.s. No. 36 (7-22 November 1969), Article 1(2).

4 Inter-American Advisory Opinion, para. 42.

5 Ibid., para. 46.

6 European Convention for the Protection of Human Rights and Fundamental Freedoms, 4 November 1950, т.T.s. No. 5 (entered into force 3 September 1953). 
juridical persons are covered. ${ }^{7}$ However, Article 34 of the European Convention and Additional Protocol 1 specifically encompass legal entities. The relevant part of Article 34 enables organizations and groups of individuals to present demands if they have been victimized by the parties to the Convention. Additionally, Protocol 1 provides protection to property that may be given a public use under certain conditions to all persons-physical or legal. In addition to property, the European system has recognized the standing of legal entities in other cases, which include the context of liberty of expression, liberty of reunion and association, and liberty of thought, conscience, and religion, among others. ${ }^{8}$

The African Charter on Human and Peoples' Rights is more similar to the American Convention, though it does not define the term individual, which is used throughout. The Charter notably does not use the term person, which opens itself up to the question of whether juridical persons might be covered. The Court did not refer to this distinction but did reference the Charter's coverage of peoples, which it concluded could potentially cover legal entities. ${ }^{9}$ The Charter does explicitly permit legal entities to denounce or communicate human rights violations in the Charter on behalf of third parties, functioning much like Article 44 of the American Convention where the entity cannot be connected to the alleged victim. ${ }^{10}$

The Court's review of the universal system of human rights concluded that the majority of the systems analyzed did not recognize the rights of legal entities." The International Covenant on Civil and Political Rights limits rights to individuals and does not accept denunciations before the Human Rights Committee from legal entities. ${ }^{12}$ Likewise, the International Covenant on

$7 \quad$ Inter-American Advisory Opinion, para. 51.

8 Ibid., para. 53 .

9 Article 20 of the African Charter on Human Rights and People's Rights, 27 June 1981, 21 I.L.M. $5^{8}$ (1982), entered into force on 21 October 1986., referenced in Inter-American Advisory Opinion, paras. $57-58$.

10 Inter-American Advisory Opinion, para. 58, citing Section 4, Rule 93(1) of the Rules of Procedure for the African Commission, 2010, under Article 55 of the African Charter the submission can be by a natural or legal person.

11 Ibid., paras. 59-62.

12 International Covenant on Civil and Political Rights, 16 December 1966, 999 U.N.T.s. 171, para. 59, citing CHR, V.S. v Belorussia, No. 1749/2008, 31 October 2011, para. 7.3 ("Given the fact that under article 1 of the Optional Protocol only individuals may submit a communication to the Committee, it considers that the author, by claiming violations of the rights of the Religious Union, which are not protected by the Covenant, has no standing under article 1 of the Optional Protocol"). 
Economic, Social and Cultural Rights does not extend rights to legal entities, though there is no jurisprudence on the point. ${ }^{13}$

The Court did recognize the myriad legal entities that exist and that the exercise of the rights of natural persons may occur via these entities: for example, freedom of expression may surface through a legal entity. These limited situations may be evaluated on case-by-case basis.

Opting to prioritize fundamental rights, private property interests were left to be resolved in domestic fora. Judge Caldes wrote a concurring opinion expressing "low receptivity" to the right of private property in the Inter-American Human Rights system, wanting to preserve the Court's primary function for protection of the most essential human rights. He noted, however, that property interests that relate to basic necessities required to maintain a dignified existence for the person and his or her family must receive protection.

\section{Recognizing the Elevated Status of Trade Unions}

The standing of trade unions in the Inter-American system of Human Rights has been solidified in Advisory Opinion OC-22, which recognizes the importance of trade unions as indispensable to safeguarding the rights of workers to organize and advance their interests. The jurisdiction of the Court to entertain contentious cases involving freedom of association advanced by trade unions has been established with the understanding that this result will facilitate broader protection and the effective exercise of workers' rights.

This decision builds on the Inter-American Court's other significant rulings that advance fundamental labor rights, including Baena-Ricardo et al. $v$ Pana$m a$, in which it affirmed that "freedom of association is of the utmost importance for the defense of the legitimate interests of workers, and falls under the corpus juris of human rights." In Baena, the Court recognized the crucial role of trade unions in the realization of freedom of association, stating that "freedom of association consists basically of the ability to constitute trade union organizations, and to set in motion their internal structure, activities and action programme, without the intervention of public authorities."14

13 International Covenant on Economic, Social and Cultural Rights, 993 U.N.T.s. 3.

14 Inter-American Court of Human Rights, Baena Ricardo et al v Panama, Merits, Reparations and Costs, Series C, No. 72, 2 February 2001, paras. 162, 170-72. See also Inter-American Court of Human Rights, Huilca Tecse v Peru, Preliminary Objections, Merits, Reparations and Costs, Series C, No. 121, 3 March 2005, para. 74. 
However, in Advisory Opinion OC-22, the Court recognized for the first time that trade unions in their own right have direct access to the Inter-American system as victims of human rights violations, as full participants in the proceedings and having full access to remedies.

Relying heavily on the Protocol of San Salvador and Article 8(1), the Court focused on the language that requires States to permit trade unions to form national federations or confederations, affiliate internationally, and function freely. ${ }^{15}$ These trade union rights were interpreted as being distinct from a worker's individual right to associate with a trade union.

Similarly, the language of OAS Charter Article 45(c) supported the conclusion that trade unions have autonomous rights, including the right to a legal personality. The Court also referenced the ILO's 1998 Declaration of Fundamental Principles and Rights at Work and Convention 87 specifically, which requires States to guarantee the rights of trade unions, federations, confederations, and worker organizations, including the right to create a constitution and rules, elect representatives, organize their administration, and formulate their plan of action.

Significantly, the Protocol-Article 19(6) —was also referenced to confirm the intention of State Parties to guarantee trade union rights as Article 8(1) (a) is one of only two provisions justiciable before the Inter-American Court. The Court was willing to recognize its jurisdiction over individual petitions in contentious cases filed by trade unions pursuant to Article 19(6), but only with regard to rights identifiable in Article 8(1)(a) when the alleged violations are directly attributable to a State Party to the Protocol.

However, American Convention Article 44 continues to provide an avenue of access when the allegations are against a State in the region that has not ratified the Protocol, but this mechanism must be tied to individual members. Likewise, provisions that fall outside of Article 8(1)(a), like the right to strike in Article 8(b)(1), can be pursued using this mechanism because the Court has clarified that it does not have direct jurisdiction to hear these cases filed by trade unions, except through Article 44, which provides the following:

Any person or group of persons, or any nongovernmental entity legally recognized in one or more member states of the Organization, may lodge

15 Additional Protocol to the American Convention on Human Rights in the Area of Economic, Social, and Cultural Rights, "Protocol of San Salvador", OAS Treaty Series No. 69, entered into force on 16 November 1999. http://www.oas.org/juridico/english/ treaties/a- $52 . h t m l$. 
petitions with the Commission containing denunciations or complaints of violation of this Convention by a State Party.

However, this vehicle is limited because trade unions cannot file under Article 44 as a victim of human rights violations, though they can seek redress for violations against their individual members, as can other legal entities.

\section{A Significant Step Forward in Trade Union Access to the Inter-American Human Rights System}

The Inter-American Human Rights Court has made significant decisions that advance fundamental labor rights, but until Advisory Opinion oc-22, trade unions have been unable to bring claims related to violations of the rights of the collective labor entity. In this important decision, the Court recognizes the vital role of trade unions in the realization of workers' rights and the autonomous nature of union rights that exist independently of individual workers and facilitate more extensive protection and effective enjoyment of workers' rights. In a region where several countries continue to experience significant violations of fundamental labor rights and where deadly and dangerous attacks against trade unionists make is impossible to exercise freedom of association, expanding trade union access to the Inter-American system of human rights will strengthen the ability of unions to fight against impunity and to advance fundamental labor rights. 